\title{
UNDERSTANDING THE FINTECH CONTINUANCE INTENTION OF INDONESIAN USERS: THE MODERATING EFFECT OF GENDER
}

\author{
Ferina NURLAILY ${ }^{\circledR}{ }^{*}$, Edlyn Khurotul AINI (D, Priandhita Sukowidyanti ASMORO (D) \\ Faculty of Administrative Science, Universitas Brawijaya, Malang, Indonesia
}

Received 9 November 2020; accepted 27 May 2021

\begin{abstract}
This research attempt to analyze risk and benefit factors as well as their influence on sustainability intention of FinTech. We elucidate the Planned Behavior Theory by including the perceived benefits and perceived risk variables to investigate its effect on intention to continue using FinTech. We also examined whether or not men and women are affected differently by the benefits and risk they perceive when using FinTech. Data were collected through online surveys, then being analyzed using GSCA. The results reveal perceived benefits are affected significantly by the convenience aspect and deliver a significant effect on FinTech continuance intention. The risk perceived by FinTech users is affected the most by legal risk. This study proves that gender is able to moderate the perceived risk influence on the intention to continue using FinTech, especially in the female user group.
\end{abstract}

Keywords: FinTech continuance intention, perceived benefit, perceived risk, gender, theory of planned behavior.

JEL Classification: D10, D14, G20, G41, G50.

\section{Introduction}

Financial Technology (FinTech) is a technology-based financial service that presents as an interesting brand new sector. According to The Financial Services Authority $(\mathrm{OJK})$, FinTech is the blending of financial services and technology that turns over a conventional business model into a moderate level. As such, today's financial activity covers a digitized remittance allowing instant remote payments. International According to International Monetary Fund (IMF), FinTech is a technology-based innovation that embodies novel business models, applications, procedures or products with a material effect associated with financial services provision.

The rapid development of FinTech is reflected in the growing number of FinTech start-ups. OJK statistically denotes as much as 157 of FinTech lending companies have been authorized by OJK and 58 FinTech payment systems are registered in Bank Indonesia (BI). However, the number expectedly keeps rising as several companies are currently in the licensing process. OJK has classified FinTech based on its innovation categories, such as; a) payment, clearing, settlement; b) e-aggregator; c) peer to peer (P2P) lending; and d) risk management and investment. P2P lending and payment system are the most popular FinTech service among society in Indonesia. Moreover, INDEF reported the contribution of Fintech to GDP increased from IDR 60 trillion in 2019 to IDR 100 trillion in June 2020.

Despite the fact that FinTech establishment in Indonesia highly increases, it does not stand out among the rest of South Asia countries, such as Malaysia, Thailand, Vietnam, Philippines and Myanmar. In an annual report by McKinsey \& Company, the data shows Indonesia still reached 5\% of FinTech penetration level, much lower than Philippines at 23\%, Vietnam at $16 \%$, and Thailand at $10 \%$. Apart from that, as the growth of digitalization in Indonesia intensifies, even one of the fastest in the world, it goes along the much likely potential elevation of FinTech development.

Nevertheless, the increasing attention to the FinTech industry is not in line with the public's belief in using these services. Sustainable use of this service is still quite questionable. People are being skeptical about using FinTech due to the presence of risks. Following the G4S Global cash report, it has been depicted that $50 \%-55 \%$ of transactions in Indonesia are still carried out in cash. G4S Chief Executive for Global Cash, Rosano, said that the public still feels more convenient in using cash since it is free to use and always available, confidential, non-pirated, and

${ }^{*}$ Corresponding author. E-mail: ferinanurlaily@ub.ac.id

Copyright $\odot 2021$ The Author(s). Published by Vilnius Gediminas Technical University

This is an Open Access article distributed under the terms of the Creative Commons Attribution License (http://creativecommons.org/licenses/by/4.0/), which permits unrestricted use, distribution, and reproduction in any medium, provided the original author and source are credited. 
smartphone-apps independent. Another risk to consider is the presence of illegal FinTech which has been reported as much as 508 entities that are not yet registered in OJK from January to March 2020 (Otoritas Jasa Keuangan, 2020). The existence of such illegal FinTech can conceivably put the customers at risk, deliver drawbacks to user experience and may even hinder its sustainable use.

The large number of illegal FinTech, therefore, induce legal companies to convince the customers to keep using their products and services as they pursue long-term success. This is a quiet challenge for FinTech companies to continuously improve their values of services offered while limiting the risks (Chan, 2015). Hence, identification of factors that influence people to continue using FinTech needs to be done. Prior studies have elaborated promoting factors that influence user intentions in the aspects of entrepreneurship and information systems (Chiang, 2013; Zhou, 2013; Liang \& Yeh, 2011). However, the study regarding simultaneous examination on benefits and risks in continuance intention of FinTech use is not much to discover, notably in developing countries such as Indonesia. This research includes gender variables to moderate the benefit and risk towards FinTech continuance intention. Rouibah et al. (2016) revealed that gender as demographic factors would play an important role as a moderating variable that affects the application of technology. The World Bank data shows that, in Indonesia, the customers who own online financial accounts are dominated by women. This indicates that men and women can might have different perceptions about the benefits and risks, affecting their intention to continue using technology.

More broadly, in this research, we analyze the effect of benefits and risks perceived on the continuance intention to use FinTech. At last, to discuss the moderating effect of gender on those relationship.

This research is expected to contribute in several aspects:

1. This study can emphasize understanding of benefits and risks perceived by FinTech's customers that can affect their intention continuity.

2. This research is intended to deliver insights for practitioners in developing strategies that shorten risks and increase benefits to encourage FinTech use.

3. This research is expected to inform FinTech companies about which factors that should be prioritized or avoided when offering FinTech services to their customers.

\section{Literature review}

\subsection{Financial technology}

In general, FinTech is the shape of technology use that creates solutions in finance. It includes the whole scope of financial products and services (Arner et al., 2015). Likewise, Financial Stability Board described FinTech as new business models, processes, products, applications, or services as result of financial service innovation which bring through technology (FSB, 2019). Arner et al. (2015) elaborated FinTech as a sustainable process evolving finance and technology to create a variety of innovations progressively and tend to be disruptive. rev: Based on Arner et al. (2016), FinTech evolution is divided into three periods; 1) FinTech 1.0 (from 1866 to 1967); 2) FinTech 2.0 (from 1967 to 2008); and 3) FinTech 3.0 and FinTech 3.5 (since 2008 until now. FinTech 3.0 emerged as a response from developed countries to the global financial crisis, which was marked by the establishment of new FinTech start-ups that directly provide financial services and products to public and business. Meanwhile, FinTech 3.5 performed as countries' reaction in Asia and Africa as developing countries to pursue economic growth and support financial inclusion.

The FinTech growth in Indonesia began in the FinTech 2.0 era, which was initiated by financial service companies, continued by FinTech 3.5 with FinTech start-ups (Agustia \& Anridho, 2020). FinTech in Indonesia grows exceptionally fast. FinTech transactions' value also showed a rising trend of $18.3 \%$ (YoY), from Rp. $22.4 \mathrm{M}$ in 2018 to Rp. $26.5 \mathrm{~B}$ in 2019 , where $95.67 \%$ of the transaction value is from digital payments. The largest transaction value during 2018 came from lending (49\%), payment (33\%), aggregator $(7 \%)$, crowdfunding (2\%), financial management (2\%), insurance technology (2\%), KYC (2\%), and others (3\%) (Aftech, 2018).

Although FinTech industries develop rapidly, there is still a shortage of academic literacy concerning the scope] (Shim \& Shin, 2016). Other than that, investigating related FinTech is still limited to user behavior, platform or provider business models, and performance aspects of the FinTech industry (Gomber et al., 2017). In fact, as an effort to encourage the growth of FinTech in Indonesia, the understanding needed is not only concerning user behavior of interest in using FinTech (FinTech adoption intention) (Kim et al., 2016; Ramos, 2017; Lee, 2017; Tran et al., 2018; Hu et al., 2019), but also interest in using FinTech continuously (Ha \& Jung, 2016; Jung, 2017). This study examined the influence of benefits and risks perceived by customers in their] intention to continue using FinTech. According to Ryu (2018), type of user (early adopters and late adopters) can be played as a moderating variable, whereas gender is the moderating variable in this study. Gender has never been tested in previous studies relating to the sustainable intention of Indonesian FinTech society.

\subsection{Theory of planned behavior}

User acceptance determines the effectiveness of implementing any information technology or information system (Davis, 1989; Karahanna et al., 1999). However, Bhattacherjee (2001) argued that long-term successful technology implementation is more affected by continuity of using technology than early adoption decisions. The infrequent, inappropriate, and ineffective use of information technology or information system by individual users contributed to the company's failure (Lyytinen \& Hirschheim, 1987), including financial technology companies. The amounts 
of prior and continued users determines the effective customer base, market share, and revenue of financial technology companies. Therefore, it is essential to research and comprehend the main factors that motivate customers to keep using FinTech and how they do it.

Continuance in this study is seen as an extension of acceptance behavior using the same arrangement of variables of pre-acceptance to elaborate acceptance and decision of continuity. Researchers assume that the acceptance model provides limited explanations and the results often contradict with observed individual user continuance intentions.

In the last few decades, research on acceptance and continuance intention to use information technology systems or information systems is associated with psychological motivation. Therefore, many theoretical models have been established to predict and explain continuance intentions to use information technology or information systems, including PC Utilization model (Triandis, 1979), Reasoned Action Theory (Ajzen \& Fishbein, 1980), Innovation Diffusion Theory (Rogers, 1983), Motivational Model (Deci \& Ryan, 1985), Social Cognitive Theory (Bandura, 1986), Technology Acceptance Model (Davis et al., 1989), and Planned Behavior Theory (Ajzen, 1991).

This study extends the Planned Behavior Theory using the variables of perceived benefit and risk. According to Ajzen (1985), this theory is developed into three principal constructs: attitudes towards behavior, subjective norms, and and the control over behavioral that is perceived. Ajzen (1991) defines perceived behavior control as a favor or distress in carrying out behavior. In term of information systems research, perceived behavior means the perception of internal and external constraints on behavior.

Theory of Planned Behavior examines behavior in situations where individual of FinTech user may not be able to control their behavior due to rapid technological changes, lack of critical data sources and required skills, or other aspects that cannot be explained by other theories such as The Reasoned Action Theory, The Model of Technology Acceptance, and The Theory of Innovation Diffusion. The desire to use or continually use technology or participate in certain behaviors may be lost due to a lack of necessary resources and skills (Ajzen, 2011). Furthermore, considering the good usage environment is the major factor for users to continue using FinTech, the Theory of Planned Behavior is fit for this study. Planned Behavior Theory contains the construct of perceived behavior control by considering factors beyond the user's control. Individual users cannot control perceived benefits and perceived risks because they result from other parties' actions outside the user's environment.

Consumers could perceive risk while using a service or buying a product. Perceived risk has two dimensions, namely, uncertainty and adverse consequences (Bauer, 1960). Dowling (1986) therewith suggests the principle is related to assorted kinds of losses, such as accomplishment, monetary, social and bodily, mental, psychosocial, frustration, time, etc. Ryu (2018) justifies the risks perceived by customers as the thought of riskiness in financial technology adoption. This study sees that the perceived risk faced by individual users of financial technology is thought to be influenced by several risks such as financial risk, legal risk, security risk, also operational risk. Chaudhuri and Holbrook (2001) defines perceived benefits as the type of convenience that consumers feel in a product or service consumed. In addition, Ryu (2018) represents perceived benefits as customer perceptions of the potential that financial technology adoption will produce a positive outcome. The perceived benefits of FinTech in this study are classified into three aspects, including economic benefits, convenience, and seamless transaction.

\section{Research methodology}

This study is a quantitative type of research with an explanatory approach, which attempts to elucidate the relation between the variables studied through empirical hypothesis testing. Cresswell (2009) defines this type of research as an explanatory approaching study through numerical data collection and mathematical data analysis.

Based on the background and literature review above, it is known that FinTech continuance intention is influenced by users' perceived benefits and risks. Economic benefits, seamless transactions, and convenience are the types of users' perceived benefits, whereas the users' perceived risks generally include financial risk, legal risk, security risk, and operational risk. These benefits and risks perceived by the users are also thought to affect FinTech continuance intention based on the gender of FinTech users. The research model is described in Figure 1 as follows.

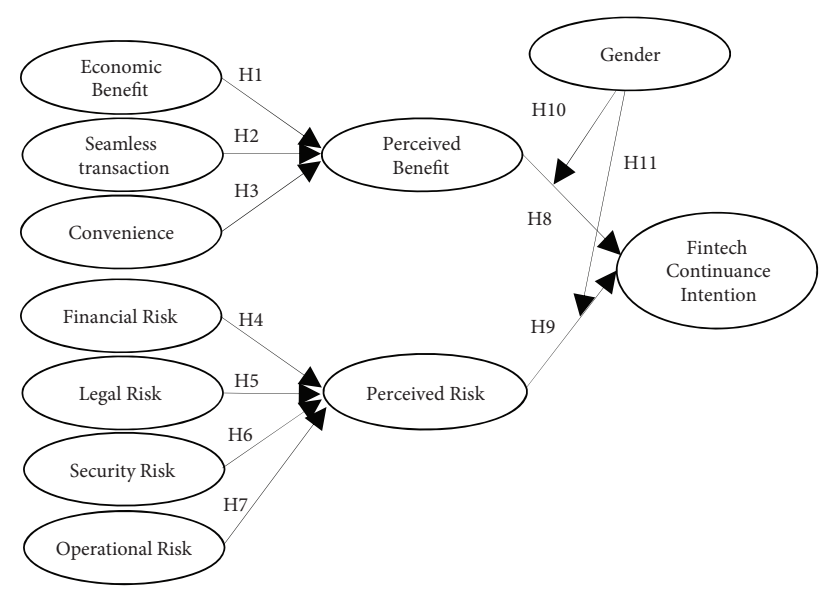

Figure 1. Research model

According to the illustration depicted in Figure 1, this research is composed of 11 hypotheses:

$\mathrm{H}_{1}$ : Economic benefit has an impact on perceived benefit.

$\mathrm{H}_{2}$ : Seamless transaction has an impact on perceived benefit.

$\mathrm{H}_{3}$ : Convenience has an impact on perceived benefit.

$\mathrm{H}_{4}$ : Financial risk has an impact on perceived risk.

$\mathrm{H}_{5}$ : Legal risk has an impact on perceived risk.

$\mathrm{H}_{6}$ : Security risk has an impact on perceived risk. 
$\mathrm{H}_{7}$ : Operational risk has an impact on perceived risk.

$\mathrm{H}_{8}$ : Perceived benefits have an impact on FinTech continuance intention.

$\mathrm{H}_{9}$ : Perceived risks have an impact on FinTech continuance intention.

$\mathrm{H}_{10}$ : The effect of perceived benefits on FinTech continuance intention on women is greater than on men.

$\mathrm{H}_{11}$ : The effect of perceived risks on FinTech continuance intention on women is greater than on men.

\subsection{Research sample and data collection}

FinTech users in Indonesia are chosen to be the studied population. This research used Cochran formula for determining sample size because the population is large and unknown (Cochran, 1977). There are two critical factors to this formula: the estimation of the levels of precision (e) and the estimation of the variance or heterogeneity of the population (p) (Bartlett et al., 2001). We calculate an ideal sample size used $5 \%$ level of precision, which is acceptable in social research (Taherdoost, 2017). Furthermore, we employed $50 \%$ occurrence of a condition as suggested by many researchers (Taherdoost, 2017) so that it will result in the maximization of variance (Bartlett et al., 2001). This study used $95 \%$ of confidence level $(Z$ value $=$ 1.96). Taherdoost (2017) stated the typical levels of confidence used in management research are $95 \%$. Based on the Cochran formula result, suggested size of sample for this study is no less than 385 .

The sampling technique used was purposive sampling by determining the research sample with several considerations or criteria to make the data collected later more representative and provide important information that cannot be obtained from other choices (Sekaran \& Bogie, 2013). From 520 questionnaires collected, there are 406 questionnaires met the criteria and can be processed for further analysis. The data were collected through an online survey for 3 months from June to August in 2020. The online questionnaires using URL address were distributed to FinTech users in Indonesia. In order to ensure the respondents understand about FinTech, we gave a short explanation at the beginning of questionnaire related FinTech. We also asked questions whether the respondents are FinTech users and what kind of FinTech they use.

\subsection{Measurement variable}

Likert scale is used to measure studied variables with the scale ranging from $1-5$, where 1 indicates strong disagreement while 5 indicates strong agreement. Proposed variables in this study were adopted from prior studies: Featherman and Pavlou (2003), Cheng et al. (2006), Kim et al. (2008), and Ryu (2018). Based on those literature review, four items were adapted to measure perceived benefit, legal risk, and FinTech continuance intention. The perceived risk, economic benefit, seamless transaction, convenience, financial risk, security risk, and operational risk is measured using three items.

\subsection{Data analysis}

Generalized Structured Component Analysis (GSCA) was performed in the validation of measurement model and structural model testing. Hwang and Takane (2004) illustrated GSCA as an alternative method to partial least squares for path analysis with the component which changes the factors implementing accurate linear combinations of observed variables.

\section{Result}

\subsection{Respondent characteristics}

Table 1 describes respondents' characteristics that shows $51.72 \%$ of respondents' age ranged from $20-24$ years old, while the gender yielded a female to male ratio of $51.48 \%$ to $48.52 \%$. The majority of educational levels were around undergraduate, with a percentage of $41.13 \%$. Furthermore, the respondents were dominated by early adopter with $81.03 \%$ who had the speed ahead of using technology. Based on their origins, it can be concluded that the respondents came from all over Indonesia, with the greatest number comes from Java.

Table 1. Respondents' characteristics

\begin{tabular}{|c|c|c|c|}
\hline Variables & Groups & Frequencies & Value (\%) \\
\hline \multirow{6}{*}{ Age } & $17-20$ & 29 & $7.14 \%$ \\
\hline & $20-24$ & 210 & $51.72 \%$ \\
\hline & $25-29$ & 41 & $10.10 \%$ \\
\hline & $30-34$ & 52 & $12.81 \%$ \\
\hline & $35-39$ & 41 & $10.10 \%$ \\
\hline & $>40$ & 33 & $8.13 \%$ \\
\hline \multirow{2}{*}{ Gender } & Female & 209 & $51.48 \%$ \\
\hline & Male & 197 & $48.52 \%$ \\
\hline \multirow{5}{*}{$\begin{array}{l}\text { Education } \\
\text { Level }\end{array}$} & $\leq$ High School & 134 & $33.00 \%$ \\
\hline & Diploma III & 12 & $2.96 \%$ \\
\hline & Undergraduate & 167 & $41.13 \%$ \\
\hline & Graduate & 84 & $20.69 \%$ \\
\hline & Post Graduate & 9 & $2.22 \%$ \\
\hline \multirow{2}{*}{ User types } & Early adopter & 329 & $81.03 \%$ \\
\hline & Late adopter & 77 & $18.97 \%$ \\
\hline \multirow{5}{*}{ Origin } & Sumatra & 35 & $8.62 \%$ \\
\hline & Java & 346 & $85.22 \%$ \\
\hline & Kalimantan & 14 & $3.45 \%$ \\
\hline & Sulawesi & 6 & $1.48 \%$ \\
\hline & $\begin{array}{l}\text { Bali \& Nusa } \\
\text { Tenggara }\end{array}$ & 5 & $1.23 \%$ \\
\hline
\end{tabular}

\subsection{Linearity assumption test}

The linearity test was performed to specify whether the SEM-GSCA model was appropriate or not. The test results show that the significance value ( $\mathrm{p}$-value linearity) of all independent variables $(\mathrm{X})$ on the dependent variable $(\mathrm{Y})$ is 0.000 , which means that the relationship pattern of these variables is stated as linear. 


\subsection{Validity and reliability construct}

The validity evaluation of the measurement model was done by analyzing at the estimated values of the factors. When a factor value has the $t$-value of $\geq 1.96$ (critical value) and or the standard factor value of $\geq 0.50$, it indicates a good validity towards the construct or latent variable. Meanwhile, the reliability evaluation on measurement model using GSCA can utilize Construct Reliability $(C R \geq 0.70)$ and Average Variance Extracted (AVE $\geq 0.50)$. Appendix 1 shows the test of validity and reliability.

\subsection{Structural model}

The evaluation of coefficient/parameters that indicate a causal relation or effect among latent variables is presented in this section. The insignificance of a causal relation is stated by critical ratio (C.R) value ranging from -1.96 to 1.96 with a 0.05 significance level. With the help of the GSCA program application, the estimated value of the structural model critical ratio can be obtained. The results of the calculation of the coefficients are summed up and demonstrated in Table 2 as follows.

As is observed from Table 2, it is evident that economic benefit shows a path coefficient of 0.141 with a CR value of 3.21. Since the $C R$ value is greater than the critical value $(3.21>1.96), \mathrm{H} 1$ is accepted. Seamless transactions and convenience give similar results which produce path coefficients of 0.213 and 0.4 with CR values of 4.01 and 8.06. These results show that seamless transactions and convenience give a significant effect on perceived benefits, which means that $\mathrm{H} 2$ and $\mathrm{H} 3$ are accepted.

In terms of risk, it can be seen that the variable of financial risk shows a path coefficient of 0.22 with a CR value of 3.58 while legal risk has a path coefficient of 0.353 with a $C R$ value of 6.22 . Because the $C R$ value is larger than the critical value (>1.96), then $\mathrm{H} 4$ and $\mathrm{H} 5$ are accepted. Similar results are shown by security risk, which also has a significant effect on perceived risk, where the path coefficient obtained is 0.145 with a CR value of 2.51 so that $\mathrm{H} 6$ is accepted. Operational risk shows different results with 0.037 of path coefficient and 0.61 of $C R$ value (smaller than the critical value of 1.96), thus, H7 is rejected. It shows that operational risk does not affect perceived risk significantly.

Furthermore, Table 2 indicates that $\mathrm{H} 8$ is accepted since perceived benefit affects FinTech continuance intention significantly. This is due to the larger CR value (14.76) compared to the critical value (1.96). Different results are shown by perceived risk with a path coefficient value of 0.069 with a $\mathrm{CR}$ value of 1.65 . As the $\mathrm{CR}$ value is smaller than the critical value $(1.65<1.96)$, H9 is rejected, which means that perceived risk do not affect significantly on the FinTech continuance intention.

\subsection{Moderated MultiGroup Analysis (MMA)}

The moderation type checking test result proves that based on Path model, $\mathrm{M}$ and $\mathrm{M}^{*} \mathrm{X}$ are insignificant. The findings are classified into the Homologizer Type moderation category, according to the Moderated Type Classification. Sub-Group Analysis or Moderated MultiGroup Analysis (MMA) followed and divided the Structural Path model into 2 groups.

Table 3. Summary of Homologizer/MultiGroup moderation analysis results

\begin{tabular}{|c|c|c|c|c|c|}
\hline $\begin{array}{c}\text { Moderation } \\
\text { Test }\end{array}$ & Group & Path & CR & Notes & $\begin{array}{l}\text { Conc- } \\
\text { lusion }\end{array}$ \\
\hline \multirow{2}{*}{$\begin{array}{l}\text { Gender }(\mathrm{M}) \\
\text { moderates } \\
\mathrm{Y}_{1} \text { toward } \\
\mathrm{Y} 3\end{array}$} & Male & 0.608 & $11.25^{*}$ & \multirow{2}{*}{$\begin{array}{l}\text { No Dif- } \\
\text { ference } \\
\text { in Signi- } \\
\text { ficance }\end{array}$} & \multirow{2}{*}{$\begin{array}{l}\text { Unable } \\
\text { to } \\
\text { mode- } \\
\text { rate }\end{array}$} \\
\hline & Female & 0.522 & $10.26^{*}$ & & \\
\hline \multirow{2}{*}{$\begin{array}{l}\text { Gender }(\mathrm{M}) \\
\text { moderates } \\
\mathrm{Y}_{2} \text { toward } \\
\mathrm{Y} 3\end{array}$} & Male & -0.028 & 0.53 & \multirow{2}{*}{$\begin{array}{l}\text { There is } \\
\text { Diffe- } \\
\text { rence in } \\
\text { Signi- } \\
\text { ficance }\end{array}$} & \multirow{2}{*}{$\begin{array}{l}\text { Able } \\
\text { to } \\
\text { mode- } \\
\text { rate }\end{array}$} \\
\hline & Female & -0.118 & $1.98^{\star}$ & & \\
\hline
\end{tabular}

Note: ${ }^{*}$ significant at 0.05 or $\mathrm{CR}>1.96$.

Table 2. Estimation results and hypothesis testing

\begin{tabular}{|c|c|c|c|c|c|c|c|c|}
\hline \multirow{2}{*}{$\begin{array}{c}\text { Sub- } \\
\text { Struc- } \\
\text { ture }\end{array}$} & \multicolumn{3}{|c|}{ Influence between latent variables } & \multirow{2}{*}{$\mathrm{H}$} & \multirow{2}{*}{ Path } & \multirow{2}{*}{ CR } & \multirow{2}{*}{ p-value } & \multirow{2}{*}{$\begin{array}{l}\text { Conclu- } \\
\text { sion }\end{array}$} \\
\hline & Exogen Var. & $\rightarrow$ & Endogen Var. & & & & & \\
\hline 1 & Economic Benefit (X1) & $\rightarrow$ & Perceived Benefit (Y1) & $\mathrm{H}_{1}$ & 0.141 & $3.21^{\star}$ & 0.001 & Sig. \\
\hline 1 & Seamless Transaction (X2) & $\rightarrow$ & Perceived Benefit (Y1) & $\mathrm{H}_{2}$ & 0.213 & $4.01^{\star}$ & 0.000 & Sig. \\
\hline 1 & Convenience (X3) & $\rightarrow$ & Perceived Benefit (Y1) & $\mathrm{H}_{3}$ & 0.400 & $8.06^{\star}$ & 0.000 & Sig. \\
\hline 2 & Financial Risk (X4) & $\rightarrow$ & Perceived Risk (Y2) & $\mathrm{H}_{4}$ & 0.220 & $3.58^{*}$ & 0.000 & Sig. \\
\hline 2 & Legal Risk (X5) & $\rightarrow$ & Perceived Risk (Y2) & $\mathrm{H}_{5}$ & 0.353 & $6.22^{\star}$ & 0.000 & Sig. \\
\hline 2 & Security Risk (X6) & $\rightarrow$ & Perceived Risk (Y2) & $\mathrm{H}_{6}$ & 0.145 & $2.51^{\star}$ & 0.012 & Sig. \\
\hline 2 & Operational Risk (X7) & $\rightarrow$ & Perceived Risk (Y2) & $\mathrm{H}_{7}$ & 0.037 & 0.61 & 0.542 & Not Sig. \\
\hline 3 & Perceived Benefit (Y1) & $\rightarrow$ & $\begin{array}{l}\text { Fintech Continuance } \\
\text { Intention (Y3) }\end{array}$ & $\mathrm{H}_{8}$ & 0.560 & $14.76^{\star}$ & 0.000 & Sig. \\
\hline 3 & Perceived Risk (Y2) & $\rightarrow$ & $\begin{array}{l}\text { Fintech Continuance } \\
\text { Intention (Y3) }\end{array}$ & $\mathrm{H}_{9}$ & -0.069 & 1.65 & 0.100 & Not Sig. \\
\hline
\end{tabular}

Note: * significant at 0.05 or CR $>1.96$. 
Based on the Moderated Multigroup Analysis (MMA) results in Table 3, it shows that gender is incapable of moderating the influence of perceived benefit on FinTech continuance intention, or H10 is rejected. As is known, there is no difference in the significance test in the two coefficient groups (both significant). In conclusion, perceived benefits significantly affect the continuance intention in using FinTech on both men and women. However, it is not moderated by gender. Before being moderated by gender, perceived benefits influence FinTech continuance intention significantly.

Table 3 also illustrates the gender moderation on perceived risk effect in continuance intention to use FinTech There are differences observed in the significance test for the two coefficients group (Females are confirmed significant while males are insignificant). Finally, it turns out that the perceived risk give a stronger effect on women than men in reducing FinTech continuance intention. Meanwhile, the effect of perceived risk on customers' intention to keep using FinTech was previously insignificant before being moderated by gender. This proves that gender can moderate the effect of perceived risk on FinTech continuance intention which makes H11 is accepted.

\section{Discussion}

FinTech is one of the developing businesses in Indonesia. In this pandemic circumstances, FinTech industries are expected to generate financial inclusion and promote economic growth by benefitting its excellence in technology. Hopefully, this research will expand knowledge related to perceived benefits, perceived risks, and continuance intention. Moreover, it can provide insights concerning perceived benefits and perceived risks that are favorable to develop strategies which can increase benefits and reduce risks, hence, people will be encouraged to use of FinTech. Furthermore, the findings hopefully will provide information for FinTech companies and help them adjust the priority when offering services.

This study discovers that perceived benefits affect the intention to continue using FinTech while perceived risk goes the other way around. These results indicate that users think more about the benefits which influence them to use FinTech continuously. The users do not feel that the existed risks will influence the continuance use of FinTech. This can be due to the possibility that users already have anticipated and manage to become responsible for using FinTech. Furthermore are needed to meet consumer demands and needs.

Concerning the factors that affect the perceived benefits, convenience gives the most significant influence since users tend to use FinTech due to its convenience. FinTech can provide instant financial services and is accessible anytime and anywhere. This study also reveals that apart from convenience, economic benefits and seamless transactions are determinants that can also encourage FinTech continuance intention. Thus, our findings give a good agreement with prior studies (Okazaki \& Mendez, 2013; Ryu, 2018).

Apart from benefit factors, risk factors are likely give impact on FinTech sustainable intention. Legal risk is the most affecting factor in perceived risk, followed by financial and security risk. Contrarily, operational risk indicates different results where it has no significant effect on risk perception. The inadequacy of government regulations and legal uncertainty for FinTech users can threaten the sustainability of FinTech businesses. In Indonesia, although there are institutions such as OJK and BI to supervise FinTech, it does not seem to completely eliminate illegal FinTech companies. In addition, the issue of financial loss, financial fraud, and personal and financial information is also a risk and is not known to FinTech users. This situation may cause users to be reluctant to associate themselves with FinTech, which in turn may form negative attitudes towards future use of FinTech. Therefore, clear regulations and supervision from the government that are appropriate for the security of financial transactions are things to put into consideration so that the Fintech business can maintain.

FinTech users were grouped into two: male and female, in order to gain the best approach possible to understand FinTech technology usage. Regarding gender, it is proved that gender is unable to moderate the perceived benefits effect on FinTech continuance intention. yet can moderate the effect of perceived risk on FinTech continuance intention. However, there is no significant difference observed in the effect of FinTech continuance intention examined from perceived benefits between men and women. This is likely because both genders are familiar with a different kind of FinTech and mutually feel the same level of benefits from FinTech services. Moreover, Bem (1981) states that the probability of variations in gender impact on intention is not limited to be measured only by the dichotomous measure of gender but more inherently based on femininity or masculinity degree. It is different from perceived risk, where the effect is stronger on women than on men in reducing FinTech continuance intention. Francis et al. (2015) stated compared to men, women are more conservative and careful of the risks. It can be illustrated that when women sense a high risk of using FinTech, it will lower the desire to use FinTech in the future. This is immensely important for FinTech industries to concern, as it may help minimize the risk from the FinTech services they offer so that their business can survive. Considering that women still dominate internet users in Indonesia, the potential for women as FinTech users in Indonesia is highly likeable.

Our results conclude support for the Planned Behavior. Theory. The theory is used in this study to examine behavior in situations where individual users of FinTech may not be able to control their behavior. Individual user intention to continue using FinTech influenced by the environment. This study showed that perceived benefit has an impact on FinTech continuance intention. The perceived 
benefit influenced by economic benefit, seamless transaction, and convenience offered by FinTech provider and beyond user's control. On the other hand, the influence of perceived risk is based on gender moderation. Financial, legal, and security risks appeared to have an impact on perceived risk and they cannot be controlled by individual users because they are resulted from the actions of other parties outside the user's environment.

\section{Conclusions and future research}

\section{Conclusions}

This research is aimed to analyze the effect of perceived benefits and risk on FinTech continuance intention, to discover benefits and risk determinants, and to acknowledge whether gender moderates the effect of perceived benefits and perceived risks on FinTech continuance intention. Results attest the significant effect given from economic benefits, seamless transactions, and convenience, on the perceived benefits of using FinTech where convenience has the most dominant influence. In other words, the more FinTech can do many transactions at once, offer low cost services, and easy to use, the more benefits can be obtained. Meanwhile, with regard to risk, several risks such as legal risk, financial risk, and security risk are the factors that give a significant effect on user-perceived risk. Based on the users, some regulations are still found unclear and the fraud possibility remains high. Some concerns about the violation of user's privacy and financial data still linger. The higher these risks can get, the greater the user's perceived risk will be.

This study also reveals that Fintech continuance intention is more dominantly influenced by perceived benefits than by perceived risk. This means that if a FinTech business wants to continue to survive and develop, it must be able to offer various benefits and added value to customers, while reducing risks by providing clear certainty. Therefore, the role of the government regarding the FinTech regulatory and supervisory system needs to be improved. Interestingly, the result reveals that gender moderation only happens on perceived risk where women are more affected. When women perceive more risks while using FinTech, it is most likely for them to drop the use.

\section{Limitation and directions for future research}

Despite of its value, this study has several limitations: (1) This study examines the overall FinTech without considering its types; (2) This study is explanatory research undertaken in a short period. Further research is needed: (1) Since the respondents were all Indonesian users, further research can be conducted overseas to examine the generalizability of the theoretical model we propose; (2) Future research can set to integrate age, experience and nationality of customers as moderators in a theoretical model to test the presence of behavior difference in sundry samples of users categorized by these properties; (3) Future research can be conducted to identify any significant difference possibility of FinTech's perceived benefits, perceived risks and continuance intentions in numerous types of FinTech.

\section{References}

AFTECH. (2018). Fintech Indonesia. Fintech. https://fintech.id/ dokumen/aftech-annual-member-survey-2018

Agustia, D., \& Anridho, N. (2020). Financial inclusion: Does Fintech help in Indonesia? In Financial Technology and Disruptive Innovation in ASEAN (pp. 149-165). IGI Global. https://doi.org/10.4018/978-1-5225-9183-2.ch008

Ajzen, I. (1985). From intentions to actions: A theory of planned behavior. In Action control (pp. 11-39). Springer. https://doi.org/10.1007/978-3-642-69746-3_2

Ajzen, I. (1991). The theory of planned behavior. Orgnizational Behavior and Human Decision Processes, 50(2), 179-211. https://doi.org/10.1016/0749-5978(91)90020-T

Ajzen, I. (2011). The theory of planned behaviour: Reactions and reflections. Psychology \& Health, 26(9), 1113-1127.

https://doi.org/10.1080/08870446.2011.613995

Ajzen, I., \& Fishbein, M. (1980). Understanding attitudes and predicting social behavior (1st ed.). Pearson.

Arner, D. W., Barberis, J., \& Buckey, R. P. (2016). FinTech, RegTech, and the reconceptualization of financial regulation. Northwestern Journal of International Law \& Business, 37,371 .

Arner, D. W., Barberis, J., \& Buckley, R. P. (2015). The evolution of Fintech: A new post-crisis paradigm. University of New South Wales Law Research Serie. Researh paper no: 2015/047. https://doi.org/10.2139/ssrn.2676553

Bandura, A. (1986). Social foundations of thought and action (1st ed., Vol. 1986). Prentice-Hall.

Bartlett, J. E., Kotrlik, J. W., \& Higgins, C. C. (2001). Organizational research: Determining appropriate sample size in survey research appropriate sample size in survey research. Information Technology, Learning, and Performance Journal, 19(1), 43.

Bauer, R. A. (1960). Consumer behavior as risk taking. Dynamic marketing for a changing world. In Proceedings of the 43rd Conference of the American Marketing Association (pp. 389398). Marketing Classics Press.

Bem, S. L. (1981). Gender schema theory: A cognitive account of sex typing. Psychological Review, 88(4), 354-364. https://doi.org/10.1037/0033-295X.88.4.354

Bhattacherjee, A. (2001). Understanding information systems continuance: An expectation-confirmation model. MIS Quarterly, 25(3), 351-370. https://doi.org/10.2307/3250921

Chan, R. (2015). Asian regulators seek fintech balance. 25 Finance Asia. https://www.financeasia.com/article/asian-regulatorsseek-fintech-balance/401588

Chaudhuri, A., \& Holbrook, M. B. (2001). The chain of effects from brand trust and brand affect to brand performance: the role of brand loyalty. Journal of Marketing, 65(2), 81-93. https://doi.org/10.1509/jmkg.65.2.81.18255

Cheng, T. E., Lam, D. Y., \& Yeung, A. C. (2006). Adoption of internet banking: an empirical study in Hong Kong. Decision Support Systems, 42(3), 1558-1572. https://doi.org/10.1016/j.dss.2006.01.002

Chiang, H.-S. (2013). Continuous usage of social networking sites: The effect of innovation and gratification attributes. Online Information Review, 37(6). https://doi.org/10.1108/OIR-08-2012-0133 
Cochran, W. G. (1977). Sampling techniques. John Wiley \& Sons.

Creswell, J. (2009). Research design-qualitative, quantitative, and mixed methods approaches. Sage Publications Inc.

Davis, F. D. (1989). Perceived usefulness, perceived ease of use, and user acceptance of information technology. MIS Quarterly, 13(3), 319-340. https://doi.org/10.2307/249008

Davis, F. D., Bagozzi, R. P., \& Warshaw, P. R. (1989). User acceptance of computer technology: A comparison of two theoretical models. Management Science, 35(8), 982-1003. https://doi.org/10.1287/mnsc.35.8.982

Deci, E., \& Ryan, R. (1985). Intrinsic motivation and self-determination in human behavior. Springer Science \& Business Media. https://doi.org/10.1007/978-1-4899-2271-7

Dowling, G. R. (1986). Perceived risk: the concept and its measurement. Psychology \& Marketing, 3(3), 193-210. https://doi.org/10.1002/mar.4220030307

Featherman, M. S., \& Pavlou, P. A. (2003). Predicting e-services adoption: a perceived risk facets perspective. International Journal of Human-Computer Studies, 59(4), 451-474. https://doi.org/10.1016/S1071-5819(03)00111-3

Financial Standard Board (FSB). (2019). FSB report assesses FinTech developments and potential financial stability implications. FSB. https://www.fsb.org/wp-content/uploads/R140219.pdf

Francis, B., Hasan, I., Park, J. C., \& Wu, Q. (2015). Gender differences in financial reporting decision making: Evidence from accounting conservatism. Contemporary Accounting Research, 32(3), 1285-1318. https://doi.org/10.1111/1911-3846.12098

Gefen, D., Straub, D., \& Boudreau, M.-C. (2000). Structural equation modeling and regression: Guidelines for research practice. Communications of the Association for Information Systems, 4(1), 7. https://doi.org/10.17705/1CAIS.00407

Gomber, P., Koch, J.-A., \& Siering, M. (2017). Digital finance and FinTech: current research and future research directions. Journal of Business Economics, 87(5), 537-580. https://doi.org/10.1007/s11573-017-0852-x

Ha, C.-S., \& Jung, D.-H. (2016). The impact of FinTech user and product characteristics on intention for continuous use. Informatization Policy, 23(4), 59-75.

Hu, Z., Ding, S., Li, S., Chen, L., \& Yang, S. (2019). Adoption intention of fintech services for bank users: An empirical examination with an extended technology acceptance model. Symmetry, 11(3), 340. https://doi.org/10.3390/sym11030340

Hwang, H., \& Takane, Y. (2004). Generalized structured component analysis. Psychometrika, 69(1), 81-99. https://doi.org/10.1007/BF02295841

Jung, L. (2017). A study on the relationship with attitude and satisfaction of the continuance intention in Fintech. Information, 20(8(B)), 5817-5824.

Karahanna, E., Straub, D. W., \& Chervany, N. L. (1999). Information technology adoption across time: a cross-sectional comparison of pre-adoption and post-adoption beliefs. MIS Quarterly, 23(2), 183-213. https://doi.org/10.2307/249751

Kim, D. J., Ferrin, D. L., \& Rao, H. R. (2008). A trust-based consumer decision-making model in electronic commerce: The role of trust, perceived risk, and their antecedents. Decision Support Systems, 44(2), 544-564.

https://doi.org/10.1016/j.dss.2007.07.001

Kim, Y., Choi, J., Park, Y.-J., \& Yeon, J. (2016). The adoption of mobile payment services for "Fintech". International Journal of Applied Engineering Research, 11(2), 1058-1061.
Lee, S. (2017). Evaluation of mobile application in user's perspective: case of P2P lending apps in fintech industry. TIIS, 11(2), 1105-1117. https://doi.org/10.3837/tiis.2017.02.027

Liang, T.-P., \& Yeh, Y.-H. (2011). Effect of use contexts on the continuous use of mobile services: the case of mobile games. Personal and Ubiquitous Computing, 15(2), 187-196. https://doi.org/10.1007/s00779-010-0300-1

Lyytinen, K., \& Hirschheim, R. (1988). Information systems failures - a survey and classification of the empirical literature. Oxford Surveys in Information Technology, 4, 257-309.

Otoritas Jasa Keuangan (OJK). (2020). Laporan Triwulan I-2020. OJK. https://www.ojk.go.id/id/data-dan-statistik/laporan-triwulanan/Documents/OJK\%20-\%20Laporan\%20Triwulan\%20 I-2020.pdf

Okazaki, S., \& Mendez, F. (2013). Exploring convenience in mobile commerce: Moderating effects of gender. Computers in Human Behavior, 29(3), 1234-1242. https://doi.org/10.1016/j.chb.2012.10.019

Ramos, F. (2017). Accessing the determinants of behavioral intention to adopt fintech services among the millennial generation. https://www.semanticscholar.org/paper/Accessing-the-determinants-of-behavioral-intention-Ramos/ bbc22583930087a8d8d237243ce2b06420374511

Rogers, E. M. (1983). Diffusion of Innovations (3rd ed.). Free Press.

Rouibah, K., Lowry, P. B., \& Hwang, Y. (2016). The effects of perceived enjoyment and perceived risks on trust formation and intentions to use online payment systems: New perspectives from an Arab country. Electronic Commerce Research and Applications, 19(3), 33-43.

https://doi.org/10.1016/j.elerap.2016.07.001

Ryu, H.-S. (2018). What makes users willing or hesitant to use Fintech?: the moderating effect of user type. Industrial Management \& Data Systems, 118(3). https://doi.org/10.1108/IMDS-07-2017-0325

Sekaran, U., \& Bougie, R. (2013). Research methods for business: A skill building approach. John Wiley \& Sons.

Shim, Y., \& Shin, D.-H. (2016). Analyzing China’s FinTech industry from the perspective of actor-network theory. Telecommunications Policy, 40(2-3), 168-181. https://doi.org/10.1016/j.telpol.2015.11.005

Sun, Q., Wang, C., \& Cao, H. (2010). An extended TAM for analyzing adoption behavior of mobile commerce [Conference presentation]. 2009 Eighth International Conference on Mobile Business. Dalian, China. https://doi.org/10.1109/ICMB.2009.16

Taherdoost, H. (2017). Determining sample size; how to calculate survey sample size. International Journal of Economics Management Systems, 2.

Tran, T., Han, K., \& Yun, S. (2018). Factors influencing the intention to use mobile payment service using fintech systems: Focused on Vietnam. Asia Life Sciences, (3), 1731-1747.

Triandis, H. C. (1979). Values, attitudes, and interpersonal behavior [Conference presentation]. Nebraska symposium on motivation. Nebraska.

Zhou, T. (2013). An empirical examination of continuance intention of mobile payment services. Decision Support Systems, 54(2), 1085-1091. https://doi.org/10.1016/j.dss.2012.10.034 


\section{APPENDIX 1}

\section{Construct Validity (Outer Model)}

\begin{tabular}{|c|c|c|c|c|c|c|c|c|}
\hline \multirow{3}{*}{$\begin{array}{l}\text { Construct / } \\
\text { Variable }\end{array}$} & \multirow{3}{*}{$\begin{array}{l}\text { Indicator / } \\
\text { Factor }\end{array}$} & \multirow{2}{*}{\multicolumn{2}{|c|}{$\begin{array}{c}\text { Partial Validity } \\
(\mathrm{LF}>0.5=\text { Valid })\end{array}$}} & \multirow{3}{*}{ Rank } & \multirow{2}{*}{\multicolumn{2}{|c|}{$\begin{array}{c}\text { Validity OverAll } \\
(\text { AVE }>0.5=\text { Valid })\end{array}$}} & \multirow{2}{*}{\multicolumn{2}{|c|}{$\begin{array}{c}\text { Construct Reliability (CR } \\
>0.7)\end{array}$}} \\
\hline & & & & & & & & \\
\hline & & Loading Factors & Notes & & AVE & Conclusion & $\mathrm{CR}$ & Notes \\
\hline \multirow{3}{*}{$\begin{array}{l}\text { Economic Benefit } \\
\text { (X1) }\end{array}$} & $\mathrm{X} 1.1$ & 0.874 & Valid & 2 & \multirow{3}{*}{0.746} & \multirow{3}{*}{ Valid } & \multirow{3}{*}{0.820} & \multirow{3}{*}{ Reliable } \\
\hline & $\mathrm{X} 1.2$ & 0.841 & Valid & 3 & & & & \\
\hline & $\mathrm{X} 1.3$ & 0.875 & Valid & 1 & & & & \\
\hline \multirow{3}{*}{$\begin{array}{l}\text { Seamless } \\
\text { Transaction (X2) }\end{array}$} & $\mathrm{X} 2.1$ & 0.800 & Valid & 2 & \multirow{3}{*}{0.659} & \multirow{3}{*}{ Valid } & \multirow{3}{*}{0.734} & \multirow{3}{*}{ Reliable } \\
\hline & $\mathrm{X} 2.2$ & 0.850 & Valid & 1 & & & & \\
\hline & $\mathrm{X} 2.3$ & 0.785 & Valid & 3 & & & & \\
\hline \multirow{3}{*}{ Convenience (X3) } & X3.1 & 0.859 & Valid & 2 & \multirow{3}{*}{0.739} & \multirow{3}{*}{ Valid } & \multirow{3}{*}{0.820} & \multirow{3}{*}{ Reliable } \\
\hline & $\mathrm{X} 3.2$ & 0.833 & Valid & 3 & & & & \\
\hline & X3.3 & 0.885 & Valid & 1 & & & & \\
\hline \multirow{3}{*}{ Financial Risk (X4) } & $\mathrm{X} 4.1$ & 0.859 & Valid & 2 & \multirow{3}{*}{0.693} & \multirow{3}{*}{ Valid } & \multirow{3}{*}{0.775} & \multirow{3}{*}{ Reliable } \\
\hline & $\mathrm{X} 4.2$ & 0.878 & Valid & 1 & & & & \\
\hline & $\mathrm{X} 4.3$ & 0.755 & Valid & 3 & & & & \\
\hline & $\mathrm{X} 5.1$ & 0.839 & Valid & 3 & & & & \\
\hline Jogal Rick (X5) & $\mathrm{X} 5.2$ & 0.902 & Valid & 1 & 0726 & Valid & 0873 & Relinble \\
\hline Legal RISK (X) & $\mathrm{X} 5.3$ & 0.795 & Valid & 4 & 0.726 & valld & $0.8 / 3$ & Keliable \\
\hline & $\mathrm{X} 5.4$ & 0.867 & Valid & 2 & & & & \\
\hline & X6.1 & 0.897 & Valid & 2 & & & & \\
\hline Security Risk (X6) & $\mathrm{X} 6.2$ & 0.807 & Valid & 3 & 0.757 & Valid & 0.838 & Reliable \\
\hline & X6.3 & 0.902 & Valid & 1 & & & & \\
\hline & X7.1 & 0.852 & Valid & 3 & & & & \\
\hline Operational Risk & $\mathrm{X} 7.2$ & 0.898 & Valid & 1 & ( & 1 & 0 & : \\
\hline$(\mathrm{X} 7)$ & $\mathrm{X} 7.3$ & 0.863 & Valid & 2 & 0.759 & Valid & 0.840 & Reliable \\
\hline & Y3.4 & 0.830 & Valid & 2 & & & & \\
\hline & Y1.1 & 0.859 & Valid & 1 & & & & \\
\hline Perceived Benefit & Y1.2 & 0.793 & Valid & 3 & $0<0$ & ג & >0م & 1: \\
\hline (Y1) & Y1.3 & 0.847 & Valid & 2 & 0.648 & Valid & 0.807 & Reliable \\
\hline & Y1.4 & 0.714 & Valid & 4 & & & & \\
\hline & $\mathrm{Y} 2.1$ & 0.749 & Valid & 3 & & & & \\
\hline Perceived Risk (Y2) & Y2.2 & 0.871 & Valid & 1 & 0.636 & Valid & 0.713 & Reliable \\
\hline & Y2.3 & 0.767 & Valid & 2 & & & & \\
\hline & Y3.1 & 0.615 & Valid & 4 & & & & \\
\hline Fintech & Y3.2 & 0.747 & Valid & 3 & 0600 & Valid & 0769 & Reliable \\
\hline Intention (Y3) & Y3.3 & 0.881 & Valid & 1 & 0.600 & valld & 0.109 & Kenladie \\
\hline & Y3.4 & 0.830 & Valid & 2 & & & & \\
\hline
\end{tabular}

